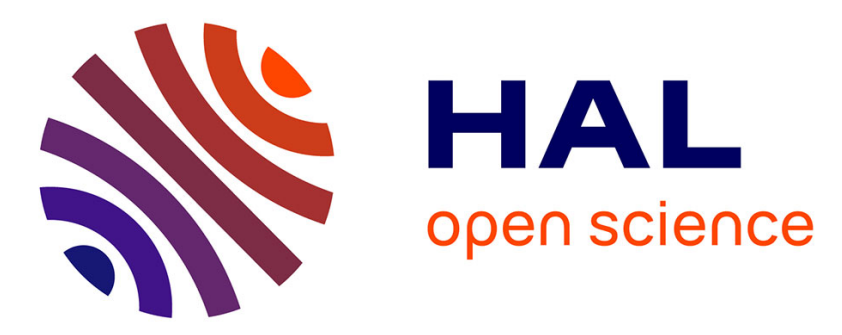

\title{
Evaluation of local ozone production of Chamonix valley (France) during a regional smog episode
}

\author{
Eric Chaxel, Guillaume Brulfert, Charles Chemel, Jean-Pierre Chollet
}

\section{To cite this version:}

Eric Chaxel, Guillaume Brulfert, Charles Chemel, Jean-Pierre Chollet. Evaluation of local ozone production of Chamonix valley (France) during a regional smog episode. Carlos Borrego; Ann-Lise Norman. Air Pollution Modelling and its Application XVII, Springer, pp.129-139, 2004, 9780387282558. 10.1007/978-0-387-68854-1_15. hal-00203627

\section{HAL Id: hal-00203627 \\ https://hal.science/hal-00203627}

Submitted on 13 Jan 2020

HAL is a multi-disciplinary open access archive for the deposit and dissemination of scientific research documents, whether they are published or not. The documents may come from teaching and research institutions in France or abroad, or from public or private research centers.
L'archive ouverte pluridisciplinaire HAL, est destinée au dépôt et à la diffusion de documents scientifiques de niveau recherche, publiés ou non, émanant des établissements d'enseignement et de recherche français ou étrangers, des laboratoires publics ou privés. 


\title{
Evaluation of Local Ozone Production of Chamonix Valley (France) During a Regional Smog Episode
}

\author{
Eric Chaxel, Guillaume Brulfert, Charles Chemel, and Jean-Pierre Chollet*
}

\section{Introduction}

During the summer 2003 a POVA Intensive Observation Period (IOP) aimed at determining the sources of airborne pollutants and monitoring their concentrations in two French Alpine valleys: the Chamonix and the Maurienne valleys (see figure 1 for geographic location). The Pollution of Alpine Valleys (POVA) program was launched in 2000 after the traffic interruption under the Mont-Blanc that followed the tragic accident in the tunnel. The Mont-Blanc tunnel was reopened at the end of 2002 and caused the high duty vehicle traffic (about 1100 trucks per day) to be back in the Chamonix valley. The summer 2003 IOP took place from 5 to 12 July in the Chamonix valley. A high ozone event occurred from 5 to 14 July at regional scales and was well characterised by measurements at rural monitoring sites. To better understand the particular atmospheric circulation, and to study the chemical reactions of airborne pollutants within the valleys, mesoscale modelling is applied. For meteorological calculation, the fifth generation PSU/NCAR Mesoscale Model (MM5) was used at scales ranging from 27 to $1 \mathrm{~km}$. MM5 was coupled with the Chemistry Transport Model (CTM) CHIMERE at regional scales and with the CTM TAPOM at a one-kilometre resolution. Simulations were performed for the period 5-12 July 2003 with different emission sets aiming at studying the impact of the international road traffic in the valley on airborne pollutant concentrations.

\section{Methodology}

Before describing atmospheric processes within the valley such as slope winds, thermal inversions and ozone production, a good description of the meteorological synoptic situation must be performed with regional models. MM5 was chosen

\footnotetext{
* E. Chaxel, G. Brulfert, C. Chemel, and J.P. Chollet, Laboratoire des Ecoulements Géophysiques et Industriels, Université Joseph Fourrier, Institut National Polytechnique de Grenoble et Centre National de la Recherche Scientifique, BP 53, 38041 Grenoble Cedex 9, France. eric.chaxel@hmg.inpg.fr
} 

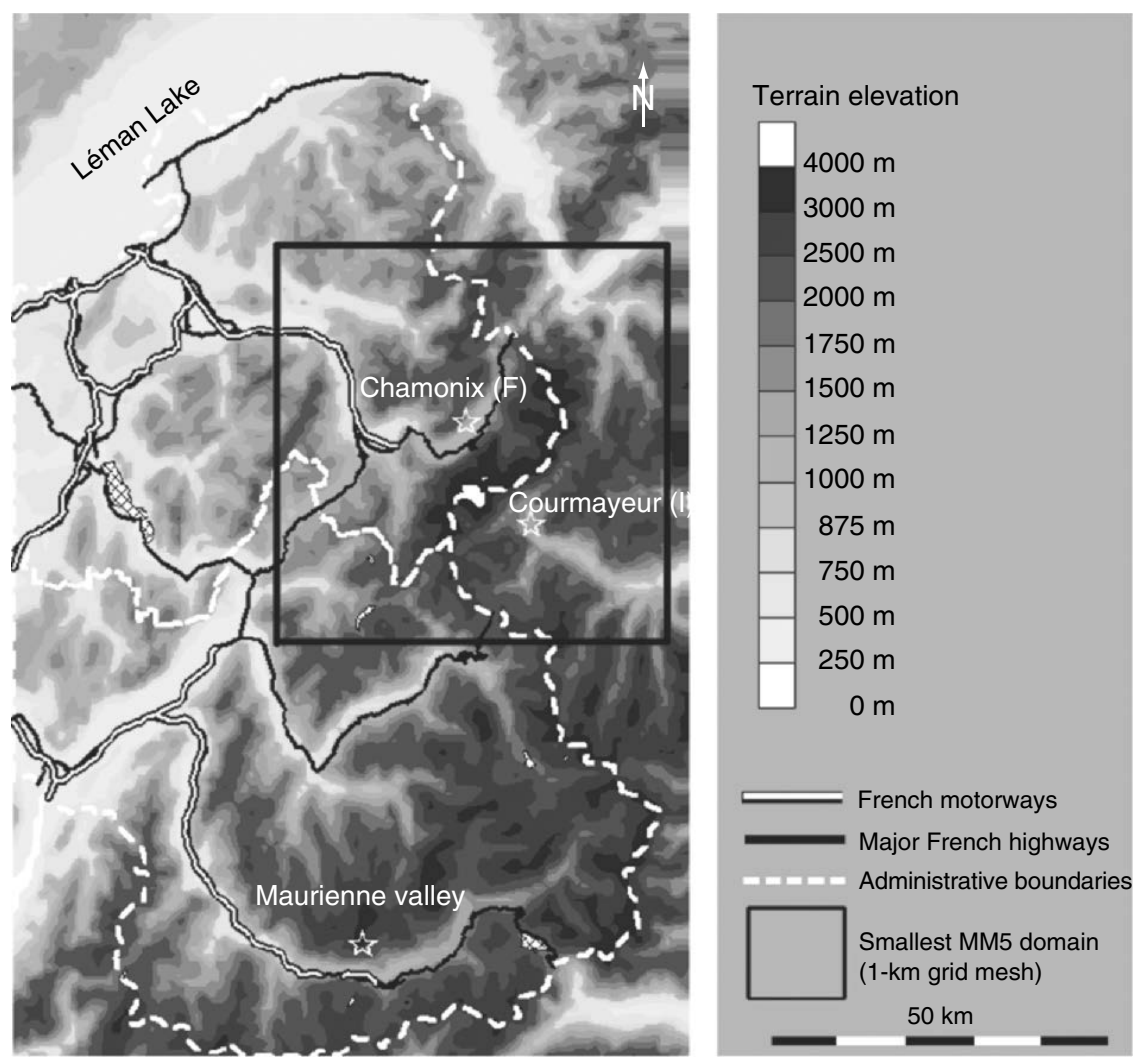

FIGURE 1. Geographical locations of major roads in the study area and of the small simulation domain.

to be used both at the regional and local scales. The two CTMs CHIMERE (Vautard et al., 2003) and TAPOM (Clappier, 1998; Gong et Cho, 1993) are then powered with MM5 meteorological fields. The interaction between the different models and domains is presented on figure 2 .

\subsection{Meteorological Calculation}

The fifth-generation PSU/NCAR mesoscale model (MM5) is a nonhydrostatic code which allows meteorological calculations at various scales with a two-way nesting technique described by Grell et al. (1994). For our simulations four different domains are used as shown in figure 2 . The smallest domain has a $1-\mathrm{km}$ grid mesh and is geographically located on figure 1 . The coarsest domain is powered with the ECMWF gridded analysis and first guess with a $0.5^{\circ}$ resolution. Vertically MM5 uses 27 sigma-pressure levels with thickness ranging from $35 \mathrm{~m}$ at the ground to $2000 \mathrm{~m}$ at $15000 \mathrm{~m}$. The top of the model is at the pressure $100 \mathrm{hPa}$. 


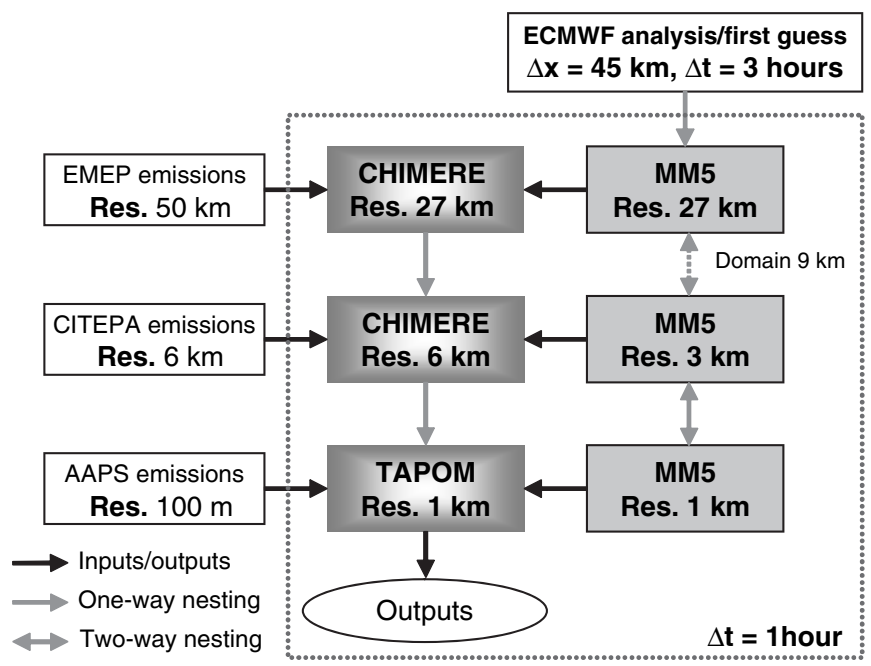

FIGURE 2. Schematic of the simulation system and its main inputs.

In this configuration the planetary boundary layer (PBL) is described with about 15 layers from 0 to $2000 \mathrm{~m}$ agl. PBL height calculation is performed by the MRF scheme described by Hong and Pan (1996).

\subsection{Chemistry Transport Calculation}

As shown on figure 2, the eulerian code CHIMERE is used in two configurations: on a domain with a $27-\mathrm{km}$ grid mesh covering Central Europe (called continental) and on a domain with a 6-km grid mesh covering Rhône-Alpes region (called regional). CHIMERE has 8 hybrid sigma-p levels with a model top set at $500 \mathrm{hPa}$ (equivalent to $5600 \mathrm{~m}$ amsl). The chemical mechanism MELCHIOR implemented in the CHIMERE code calculates concentrations of 44 species following a set of 116 reactions. MELCHIOR was developed by Derognat (1998) based on EMEP mechanism. CHIMERE is powered off-line with MM5 meteorological fields (see the model technical documentation for details). The cloud effects and dry deposition are taken into account in ozone production and destruction. Both domains run from 2 to 14 July 2004. Results for 20 MELCHIOR species matching RACM species from the regional domain are then used at the boundaries and on top of the TAPOM model. TAPOM runs from 5 to 12 July 2004.

TAPOM is an eulerian model that deals with transport, diffusion, chemistry and dry deposition in a $1 \times 1 \mathrm{~km}$ grid mesh with 12 terrain-following vertical levels. The Regional Atmospheric Chemistry Mechanism (RACM) (Stockwell et al., 1997) implemented in TAPOM resolves chemistry with 77 species and a set of 237 reactions. Chemical concentrations calculated on the regional domain of CHIMERE are linearly interpolated on the TAPOM levels. 
Nested domains at continental and regional scales provide a good description of the temporal variation of background concentrations of ozone and of other secondary species. Over this one-week simulation CHIMERE correctly deals with the important smog episode that occurred at continental scale during the period 5-12 July 2003.

\subsection{Emission Inventories}

As shown in figure 2, the EMEP emission inventory of 2001 for NOx, SOx, CO, NMVOC and $\mathrm{NH}_{3}$ on a $50-\mathrm{km}$ grid mesh is used in the continental domain (at a 27-km resolution) of CHIMERE model by recalculating emissions following the land use. The EMEP emission inventory is described by EEA (2003). To perform chemistry-transport calculations at $6-\mathrm{km}$ resolution in the regional domain of CHIMERE for the Rhône-Alpes region a 6-km resolution emission inventory from CITEPA (Bouscaren et al., 1999) is used for NOx, CO, NMVOC and SOx. At the smallest scale an accurate emission inventory based on the CORINAIR methodology and developed in the framework of the POVA program by Air de l'Ain et des Pays de Savoie with a 100-m resolution is distributed on the 1-km grid mesh used for the TAPOM calculation. Biogenic emissions are recalculated by CHIMERE following land use and temperature and for the small domain are included in the $100 \mathrm{~m} \times 100 \mathrm{~m}$ inventory provided for the POVA program.

\subsection{Definition of the Emission Scenarios}

Beside the base case two scenarios for emissions are considered. The base case (BC) takes into account all the emissions for 2003. The first scenario (S1) aims at determining which part of ozone is produced by the vehicles using the MontBlanc tunnel between France and Italy. This international traffic is mainly located along the RN 205 road. Emissions are computed based on 1-km emissions by assigning multiplicative factors to each type of sources. The second scenario (S2) aims at determining which part of ozone is produced by all the sources in the valley, biogenic and anthropogenic and then all emissions are set to zero. For the first scenario road counting realized by local agencies were used to accurately determine the part of the international traffic in the total traffic.

\section{Results}

\subsection{Description of the Base Case (BC)}

The validation of the meteorological fields from MM5 was realised using ground station data, a tethered balloon, an instrumented cable car and an UHF windprofiler radar located in Chamonix. MM5 correctly describes the two valley wind systems and the wind switch between the systems that occurs at 0600 GMT and 2000 GMT as shown on figure 3. 


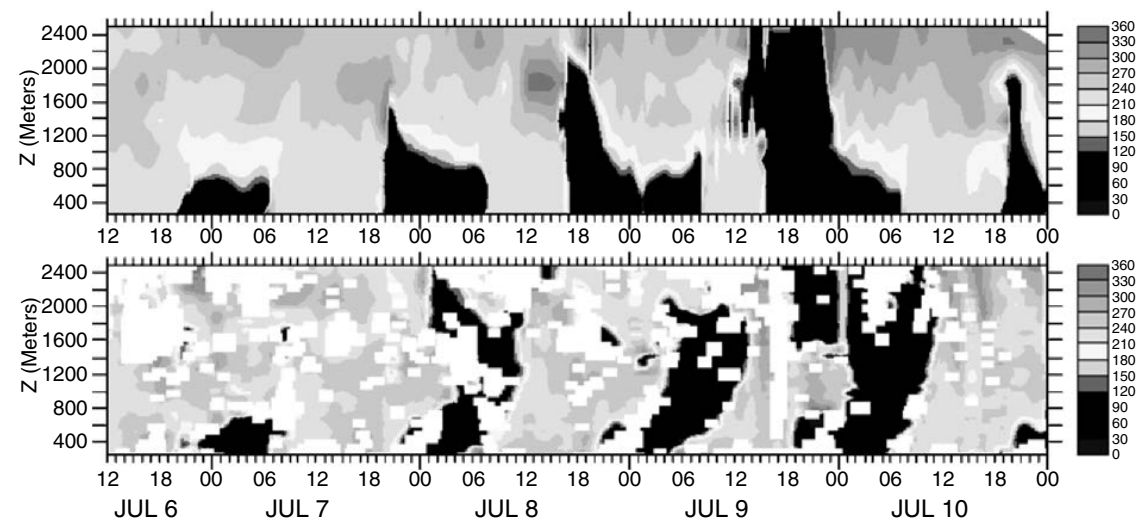

FIGURE 3. Wind direction (in degrees clockwise from north) modelled by MM5 (up) and measured with UHF radar (down) from 250 to $2500 \mathrm{~m}$ above the ground at the vertical of Chamonix from 6 to 10 July. The two wind switches occur every day at 0600 UTC and 2000 UTC.

As shown on the figure 3 the southwesterly wind resulting from slope winds and blowing in the valley axe from 0600 UTC to 2000 UTC has a vertical extent of $1300 \mathrm{~m}$ agl. During the night the northeasterly valley wind blows from 2000 UTC to 0600 UTC and has a vertical mean extend of $500 \mathrm{~m} \mathrm{agl}$ at the vertical of Chamonix. Figure 4 shows that on 8 July morning MM5 calculates PBL heights that are twice greater than heights determined from the available measurements. However the maximum PBL height of $1300 \mathrm{~m}$ agl that is reached at 1400 UTC is well reproduced.

The validation of chemical-transport calculation for the base case on figure 5 shows very good agreement with hourly measurements of ozone at rural and ranged sites. Two comparisons are shown on figure 6 and figure 7 respectively for

FIGURE 4. Determination of PBL height growth during the morning with MM5 (line), tethered balloon (triangles) and windprofiler (dots) on 8 July. Timescale is UTC.

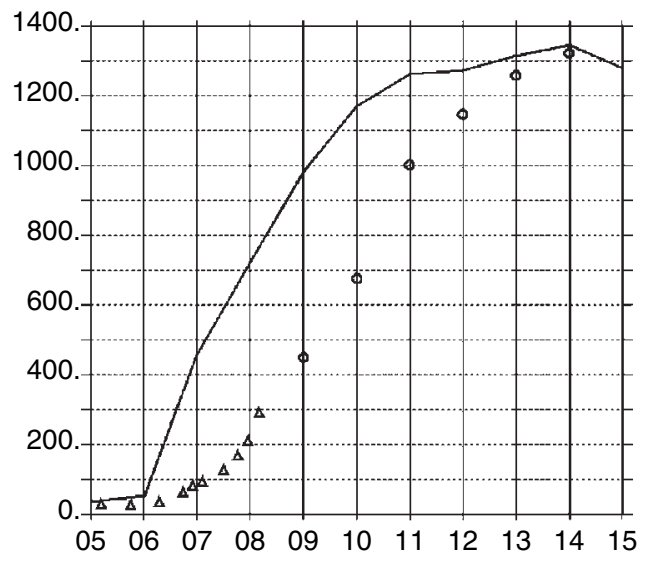




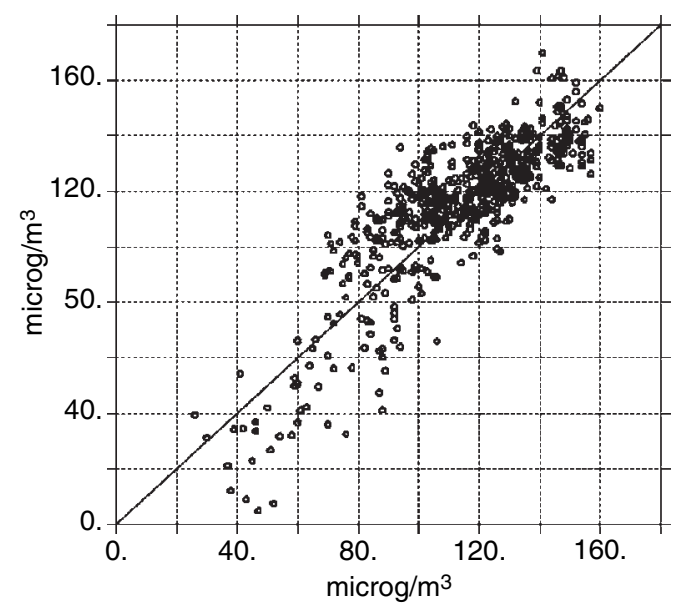

FIGURE 5. Modelled (y axis) versus observed (x axis) hourly concentrations of ozone (in $\left.\mu \mathrm{g} / \mathrm{m}^{3}\right)$ at two rural sites (les Houches, Argentière) and two high-altitude sites (plan de l'Aiguille, col des Montets).

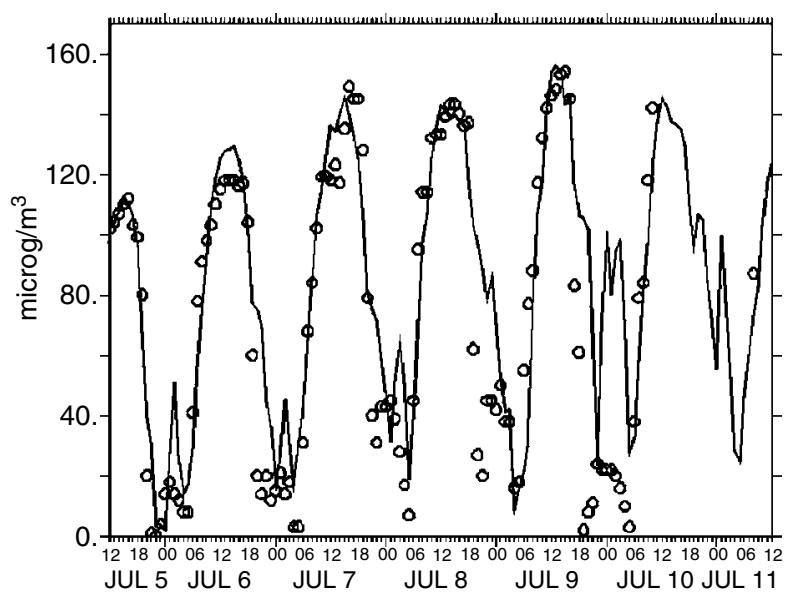

FIGURE 6. Measured (dots) and modelled (line) hourly concentrations of ozone at the suburban station Clos de l'Ours from 8 to 12 July 2003.

the suburban site Clos de l'Ours (1100 m amsl) and for the high-altitude site col des Montets (1465 m amsl). For other pollutants such as nitrogen dioxide, temporal variations are slightly less satisfactory described at source-influenced sites but still in agreement with the measurements at background sites located in the Chamonix urban area and at ranged sites.

TAPOM results and measurements both show different temporal evolutions of ozone concentrations following the part of the domain and the typology of the monitoring site. The ranged site col des Montets (on figure 7) catches very well the increase of ozone concentrations in the free troposphere from 5 July to 9 July. After 9 July the ozone concentration does not exceed $140 \mu \mathrm{g} / \mathrm{m}^{3}$. At sites located 


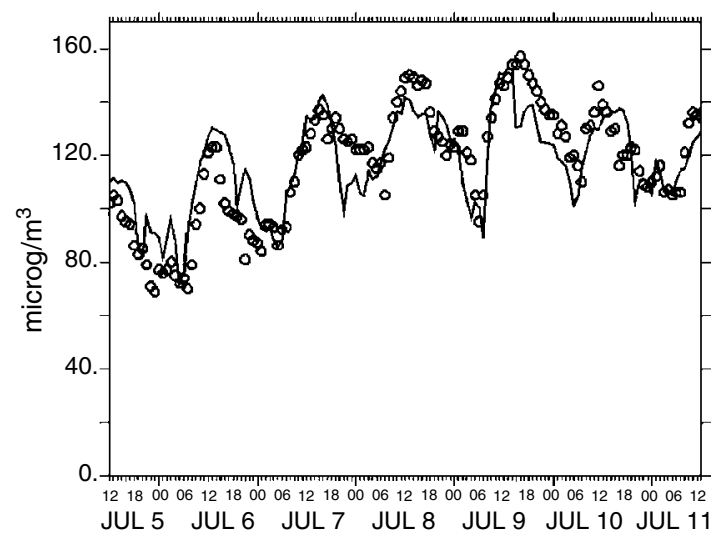

Figure 7. Measured (dots) and modelled (line) hourly concentrations of ozone at the ranged station col des Montets from 8 to 12 July 2003.

at the bottom of the valley, as Clos de l'Ours on figure 6, diurnal variations of ozone concentrations are well modelled with low values at night characterising source-influenced sites.

During the day from 0600 UTC to 2000 UTC (as stated by figure 3 ) the valley wind system is composed of up-slope winds generated by convection and of the resulting main valley wind blowing in the central part of the valley with a mean speed of $5 \mathrm{~m} / \mathrm{s}$. This system is performing a very effective dispersion and a fast transport of ozone precursors from the sources to higher altitude areas. The combination of the main valley wind and of slope winds causes the formation of two ozone plumes downwind of the Chamonix urban area. The production of ozone in the plumes is enhanced by the availability on the slopes of the valley of large amounts of biogenic VOC such as terpenes. The simulated production rate of ozone in the central part of the valley is $2 \mu \mathrm{g} / \mathrm{m}^{3} / \mathrm{h}$ whereas it reaches $5 \mu \mathrm{g} / \mathrm{m}^{3} / \mathrm{h}$ on the south face of Aiguilles Rouges mountains. This transport starts when the valley wind sets up at 0600 UTC and is really effective from 0800 UTC to noon. The calculated ozone peak in the plumes reaches $170 \mu \mathrm{g} / \mathrm{m}^{3}$ on 9 July while the background is $150 \mu \mathrm{g} / \mathrm{m}^{3}$ what represents a net production in the valley of $20 \mu \mathrm{g} / \mathrm{m}^{3}$.

The BC simulation highlights that the ozone maximums are linked with the ozone background level because of intensive mixing that brings air from free troposphere. With sunset the convection stops and the valley wind weakens progressively to become null at 1800 UTC. The atmosphere becomes stable and primary pollutants such as NOx are accumulated in the surface layer. Titration of ozone by NO and dry deposition cause the ozone concentrations to rapidly decrease at urban and suburban sites. On figure 6 the concentration reaches $0 \mu \mathrm{g} / \mathrm{m}^{3}$ at 1900 UTC on 9 July at the site Clos de l'Ours. At ranged sites such as col des Montets ozone concentration are under the control of long distance transport and dry deposition and so shows low-amplitude variations. 


\subsection{Impact of International Traffic on Ozone Production (scenario S1)}

The simulation performed without the emissions of the tunnel gives very similar results as the base case during the day because of the strong dependency of ozone concentrations in the valley with the regional background. However the simulation shows that the two ozone plumes downwind of Chamonix have lower concentrations. Depending on the day the difference between the base case and the case without tunnel emissions is in the range $2-7 \mu \mathrm{g} / \mathrm{m}^{3}$ as shown on figure 8 .

\subsection{Impact of all Local Sources on Ozone Production (scenario $S 2$ )}

In order to determine the total production of ozone in the valley a simple way to proceed is to set all the emissions of the valley to zero. In this case the processes that efficiently control the variation of ozone concentration are: long distance transport by advection, mixing, UV radiation and dry deposition. Depending on the day the difference between ozone maximums in the base case and in the scenario $\mathrm{S} 2$ is in the range $8-27 \mu \mathrm{g} / \mathrm{m}^{3}$ as shown on figure 8 what is roughly 5 to $15 \%$ of ozone peak. The figure also shows that the local production in the domain was the most effective on 9 July. This day was characterised by very weak winds that enhanced ozone production. Although ozone production in the model domain is clearly detected by the simulation (figure 8) some monitoring sites do not experience a reduction in ozone with scenario S2. Table 1 shows that ozone concentration is even higher in scenario S2 at the 4 sites located upwind of Chamonix and in the Chamonix urban area. This result is explained by the NOx-saturated (VOC-limited) regime of ozone production in this part of the valley as shown by Brulfert et al. (2003). Table 1 shows also that only sites located downwind of Chamonix experience ozone reduction except on 8 July when all sites experience reduction.

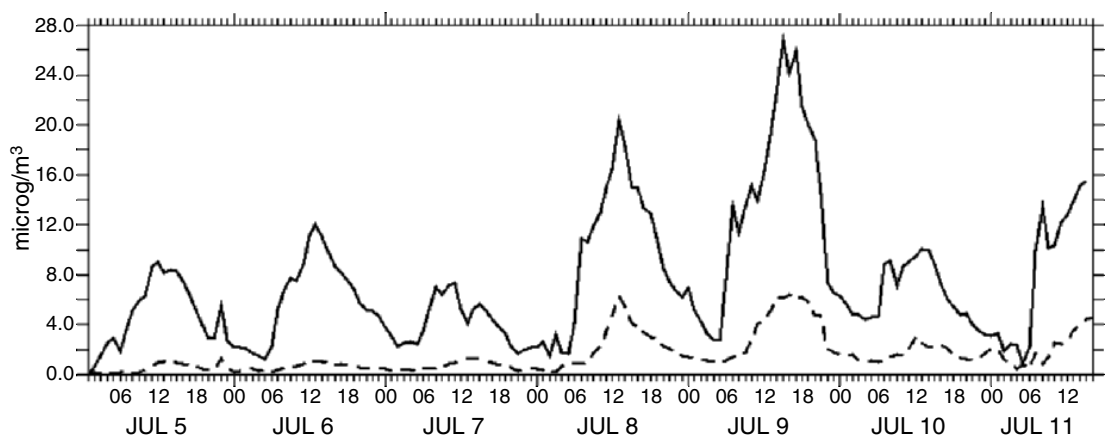

FIGURE 8. Difference between the ozone peaks in BC and in S1 (dashed line) and in BC and in S2 (solid line). Positive values indicate that the peak values of $\mathrm{BC}$ are always greater than values calculated for S1 and S2. 
TABLE 1. Maximum reduction of hourly ozone concentrations (in $\mu \mathrm{g} / \mathrm{m}^{3}$ ) at monitoring sites by applying S2. (+) indicates augmentation, (-) indicates diminution.

\begin{tabular}{|c|c|c|c|c|c|c|c|c|c|}
\hline Site & Typology & $\begin{array}{l}\text { Downwind } \\
\text { of } \\
\text { Chamonix }\end{array}$ & $\begin{array}{c}\text { Sat. } \\
05 / 07\end{array}$ & $\begin{array}{c}\text { Sun. } \\
06 / 07\end{array}$ & $\begin{array}{l}\text { Mon. } \\
07 / 07\end{array}$ & $\begin{array}{c}\text { Tues. } \\
\text { 08/07 }\end{array}$ & $\begin{array}{c}\text { Wed. } \\
09 / 07\end{array}$ & $\begin{array}{c}\text { Thu. } \\
\text { 10/07 }\end{array}$ & $\begin{array}{c}\text { Fri. } \\
11 / 07\end{array}$ \\
\hline Houches & Rural & no & $-5(+)$ & $-5(+)$ & $-3(+)$ & $1(-)$ & $-6(+)$ & $-4(+)$ & $-2(+)$ \\
\hline Bossons & Traffic & no & $-2(+)$ & $-3(+)$ & $-1(+)$ & $4(-)$ & $-8(+)$ & $-3(+)$ & $-2(+)$ \\
\hline Clos de l'O. & Suburban & no & $-2(+)$ & $-3(+)$ & $-1(+)$ & $4(-)$ & $-8(+)$ & $-2(+)$ & $-1(+)$ \\
\hline Chamonix & Centre & no & $-2(+)$ & $-3(+)$ & $-1(+)$ & $6(-)$ & $-3(+)$ & $-2(+)$ & $2(-)$ \\
\hline Plan de l'A & Ranged & yes & $4(-)$ & $3(-)$ & $2(-)$ & $10(-)$ & $10(-)$ & $3(-)$ & $8(-)$ \\
\hline Bouchet & Suburban & yes & $0(-)$ & $-2(+)$ & 0 & $7(-)$ & $5(-)$ & $1(-)$ & $3(-)$ \\
\hline Argentière & Rural & yes & $4(-)$ & $3(-)$ & $2(-)$ & $12(-)$ & $18(-)$ & $6(-)$ & $12(-)$ \\
\hline Montets & Ranged & yes & $6(-)$ & $5(-)$ & $3(-)$ & $14(-)$ & $14(-)$ & $9(-)$ & $10(-)$ \\
\hline
\end{tabular}

The ozone production in the valley only occurs in the region downwind of Chamonix except days when large amounts of photochemical secondary species regionally transported from outside to the valley modify the ozone production regime to NOx-limited (VOC-saturated). Anywhere else at the valley bottom destruction occurs even during the day.

\section{Conclusion}

This numerical study based on a chain of nested models highlighted the processes of production and destruction of tropospheric ozone in the very narrow valley of Chamonix (France) for the period 5-12 July 2003. Two pure academic cases of emission reduction in the valley showed that ozone concentrations were regionally controlled during the day whereas during the night under stable conditions the valley was totally decoupled from synoptic conditions. The precursors emitted by the Chamonix urban area and by the traffic are rapidly dispersed during the day and two plumes were modelled downwind of Chamonix. The net ozone production in the valley during the day accounts for 5 to $15 \%$ of the ozone peaks which are in the range $110-170 \mu \mathrm{g} / \mathrm{m}^{3}$ depending on the day. The impact of the tunnel accounts for about $5 \%$ of these peaks. A dependency of ozone production regime with regional background of photochemical secondary species has been observed with simulations on 8 July but must be confirmed by a three-dimension field investigation. The aim of this study was also to evaluate the ability of MM5, which is a regional model dedicated to prediction, to provide meteorological fields for a CTM with a 1-km grid mesh. Even if MM5 fields gives good results for ozone at this scale it remains too coarse to resolve fine scale processes that control concentrations of primary pollutants such as nitrogen oxides. Additional simulations with MM5 at a 500-m scale showed that the model was unable to work at such scales in a so complex terrain because processes such as slope winds were resolved twice, explicitly and by the PBL scheme, and causes unrealistic instabilities to occur near the ground. The use of the MM5 model in our modelling applications will be limited at a 1-km scale until further improvements. 
Acknowledgements The POVA program is supported by Région Rhône Alpes, ADEME, METL, MEDD. Meteorological data are provided by ECMWF, emission inventories by EMEP, CITEPA, GIERSA and Air de l'Ain et des Pays de Savoie.

\title{
References
}

Bouscaren, R., Riviere, E. and Heymann, Y., 1999, Réalisation d'un Inventaire d'Emissions Simplifiées pour la Ville de Grenoble, in Convention n98338001, CITEPA 392.

Brulfert, G., Chaxel, E., Chemel, C. and Chollet, J.P., 2003, Numerical simulation of air quality in Chamonix valley, use of different chemistry indicators, $14^{\text {th }}$ IUAPPA International Conference Air quality, Dubrovnik, Croatia, pp 661-667.

Clappier, A., 1998, A correction method for use multidimensional time splitting advection algorithms: application to two and three dimensional transport, Mon. Wea. Rev. 126: 232-242.

Derognat, C., 1998, Elaboration d'un Code Chimique Simplifié Applicable à l'Etude de la Pollution Photooxydante en Milieu Urbain et Rural, Diploma thesis report, Université Pierre et Marie Curie, France.

European Environmental Agency (EEA), 2003, EMEP/CORINAIR Emission Inventory Guidebook - 3rd edition, European Environmental Agency.

Gong, W. and Cho, H.-R., 1993, A numerical scheme for the integration of the gas phase chemical rate equations in a three-dimensional atmospheric model, Atmos. Env. 27A: 2147-2160.

Grell, G.A, Dudhia, J. and Stauffer, J., 1994, A Description of the Fifth-Generation Penn State/NCAR Mesoscale Model (MM5). NCAR Tech Note TN-398, 122 pp.

Hong, S.-Y. and Pan, H.-L., 1996, Nonlocal boundary layer vertical diffusion in a mediumrange forecast model, Mon. Wea. Rev. 124: 2322-2339.

Stockwell, R., Kirchner, F., Kuhn, M. and Seefeld, S., 1997, A new mechanism for atmospheric chemistry modelling, J. of Geophys. Res. 102(D22): 25847-25879.

Vautard, R., Martin, D., Beekmann, M., Drobinski, P., Friedrich, R., Jaubertie, A., Kley, D., Lattuati, M., Moral, P., Neininger, B. and Theloke, J., 2003, Paris emission inventory diagnostics from ESQUIF airborne measurements and chemistry transport model, J. Geophys. Res. 108(D17): 8564.

\section{Evaluation of Local Ozone Production of Chanonix Valley (France) During a Regional Smog Episode}

\author{
Speaker: E. Chaxel
}

\section{Questioner: D. Steyn}

Question: In the map Riviera modeling study, we had substantial difficulty capturing topographic shading (or shadowing) effects. Given the step topography in your domain, how did you deal with this problem?

Answer: No sensitivity tests have been made by now on the impact of the shadowing effect on the dynamical calculation since MM5 does not include a radiation module taking into account the topographic shading. About these effects they are thought to cause the MM5 model to overestimate the PBL height during the 
morning and the evening transitions. For our air quality applications this problem has to be tackled especially in winter. The impact of shading on photochemistry has been studied and has very little effect on ozone concentration.

Questioner: P. Builtjes

Question: You are using Chimere down to $6 \times 6 \mathrm{~km}$ ? And then use TAPON down to $1 \times 1 \mathrm{~km}$ ? Why do you not use Chimere down to $1 \times 1 \mathrm{~km}$ ? Going from one model to another model often creates problems.

Answer: We did not use CHIMERE down to $1 \times 1 \mathrm{~km}$ because the CHIMERE model has never been used at such a fine resolution and on the other hand the actual version of the CHIMERE model can not have a model top higher than 500 $\mathrm{mb}$ and the highest point in our $1 \times 1 \mathrm{~km}$ gridcell domain was around the pressure $500 \mathrm{mb}$ (Mont-Blanc summit) what makes the model in its original version unusable. Future versions of CHIMERE may use a higher top level. The main problem from going to CHIMERE to TAPOM is the use of different chemical mechanisms. TAPOM uses RACM mechanism and CHIMERE uses MELCHIOR mechanism. These two mechanisms are different in a such extent that RACM is a bit more detailed than MELCHIOR considering the NMVOC splitting but the main photochemical species such as ozone, PAN, formaldehyde or nitric acid are individual species and are present in the two mechanisms. 